\title{
The Effect of a Music Curriculum on the Reading Performance of Preschoolers in Singapore
}

\author{
Carol Boon Peng Loy-Ee \\ Early Childhood Curriculum Department, Kinderland Educare Services \\ Block 87, Marine Parade Central, \#03-202, Singapore 440087 \\ Tel: 65-6342-5615 E-mail: carol.loy@ kinderland.com.sg \\ Noel Kok Hwee Chia (Corresponding author) \\ Patricia Mui Hoon Ng \\ National Institute of Education, Nanyang Technological University \\ 1 Nanyang Walk, Singapore 637616 \\ Tel: 65-6219-6031 E-mail: kokhwee.chia@nie.edu.sg \\ URL: http://dx.doi.org/10.5296/ijld.v5i1.7039
}

Doi:10.5296/ijld.v5i1.7039

\begin{abstract}
This study explores from an intervention perspective what many believe - that music contributes to preschool-age children's awakening to different subject matters, particularly to reading and writing. Music can be a very powerful tool for evoking emotions; therefore its use as a stimulus for positive emotions makes it an incubator for children's growth in literacy concepts that are weaved into it. Thus, a quasi-experimental design was used to investigate the effect of a preschool music curriculum on children's reading aptitude. Post-tests showed that the reading age of the experimental group receiving the music curriculum was significantly higher than a control group with a very large effect size. The implication is that a music curriculum can be used as an efficient complementary educational approach to facilitate the development of word recognition abilities in preschool. This may eventually help reduce reading difficulties when children enter primary school.
\end{abstract}

Keywords: Curriculum, Music, Preschool, Reading

\section{Introduction}

Music can be a very powerful tool for evoking emotions; therefore its use as a stimulus for positive emotions makes it a desirable incubator for children's growth in literacy concepts that can be weaved into it. Its use in preschool settings often involves nursery rhymes and lullaby songs that are appealing to young children. Besides the appeal of these rhymes and songs in bringing joy and comfort of home to their ears, the children's familiarity with the sounds of words and letters can serve as the bedrock for learning the corresponding graphical representations in print. It is through this and various other ways that music can contribute to preschool-age children's awakening to different subject matters, particularly to reading and writing. That being said, the effect of a music curriculum on preschool children's reading aptitude has not been formally studied in Singapore; therefore it is imperative that research be carried for this purpose. It is also hoped that the search for the evidence of effectiveness and the review of literature on the ways in which music can be used for the development of literacy 
skills would bring value-added knowledge to benefit the various stakeholders in the early childhood sector.

\section{Literature Review}

Word recognition is a skill that most children are introduced to in preschool, if not done earlier in informal ways at home. It is a skill that can be learnt in two ways, via whole-word recognition or phonological decoding (see Figure 1). The first refers to the use of word-specific patterns (orthographic coding) to recognize new words and their pronunciation, while the latter refers to the use of letter-sound correspondences (phonological coding) to decipher the pronunciation of words that are new to the reader.

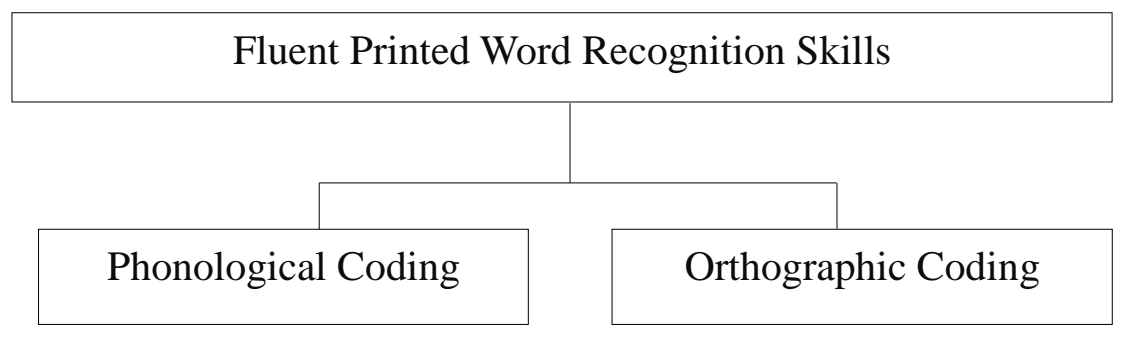

Figure 1. Cognitive components of fluent printed word recognition skills (adapted from Pennington, Peterson, \& Mcgrath, 2009)

According to Moseley (2004), a mixed approach is used by most teachers in early literacy work; i.e. they teach the whole-word recognition of 'sight' words, as well as the analytic recognition of 'phonic' words. 'Sight' words would involve high frequency words that often have irregular spellings, while 'phonic' words would involve regular words beginning usually with the teaching of consonant-vowel-consonant (CVC) words and moving on to more complex patterns including clusters and digraphs). That being said, Moseley (2004) pointed out that there are no tags attached to words to indicate whether they are regular or irregular, high or low in frequency, or rhyme with a family of other words for beginning readers. Hence, it is the interest of the texts used rather than their graded vocabulary or phonic complexity that is considered to be of paramount importance to many educationalists.

It is therefore unsurprising that familiar nursery rhymes and lullaby songs are often the choice of text used for their appeal to children in preschool literacy settings. Besides the appeal of such texts, Wigram and Gold (2006) suggested that music can provide an additional motivation to learn as it appears to enable children with communication difficulties to feel comfortable and relaxed; thus their engagement in learning is increased. This engagement might then be used as a leverage to help them build up a core word-recognition vocabulary of high frequency words, as well as acquire the phonological skills that will enable them to decode more complex and less commonly used words. Equipped with this as a foundation, children can progressively read unfamiliar words by analogy from familiar words (Ehri and McCormick, 1998).

Many studies have been carried out to show the different ways in which music can help build the foundation for literacy. As a mnemonic device, music can facilitate the retention and retrieval of information; hence it helps in learning and relearning information (Ashcraft, 2006; Gfeller, 1983; Rainey \& Larsen, 2002). For example, Rainey and Larsen (2002) in their experimental study found that familiar melodies have a positive effect on initial learning and long-term memory for unconnected text. This is further supported by studies which showed that combining text and melody can facilitate connection and help in retention and recall (Chazin \& Neuschatz, 1990; McElhinney \& Annett, 1996; Samson \& Zatorre, 1991; Wallace, 
1994). Using an experimental study, Wallace (1994) showed the effect of melody on recall of text and pointed out that music, through its rich structures in a song's melody, can help listeners to focus on surface characteristics, thus text perception is made easier.

By making text perception easier, it is likely for children to acquire both whole-word recognition and phonological skills more quickly. Indeed, the link between music and phonological awareness for preschoolers has already been established in both correlational and experimental studies (Anwari, Trainor, Woodside, \& Levy, 2002; Bolduc, 2009; Degé \& Schwarzer, 2011). Degé and Schwarzer (2011) for instance, used an experimental study with random assignment to find the effect of a music program incorporated with phonological awareness training. At pre-test, there were no differences in the forty-one preschoolers (22 boys) with respect to age, gender, intelligence, socioeconomic status, and phonological awareness. At post-tests, however, the two experimental groups that received training on phonological awareness through the music and phonological skills programs respectively had significant improvements in their phonological awareness, but not the control group that received sports training. The implication was that training in phonological awareness can be done not just with a phonological skills program but a music program as well.

Degé and Schwarzer (2011) also suggested that the results could serve as evidence of a shared sound category learning mechanism for language and music at preschool age. This is well supported with studies which suggested that music and language share common resources or neural network for processing (Besson \& Schon, 2003; Brown, Martinez, \& Parson, 2006; Fredorenko, Patel, Casasanto, Winawer, \& Gibson, 2009; Schon et al., 2010; Schon, Gordon, $\&$ Besson, 2005). Besides phonological awareness, factors such as speech segmentation (François, Chobert, Besson, \& Schön, 2013; Schon et al., 2008), processing of linguistic syntax (Koelsch, Gunter, Wittfoth, \& Sammler, 2005), and even the cognitive development of preschoolers (Moreno et al., 2011) have all been positively linked to music-based training.

In view of the overwhelming evidence regarding the benefits of music-based training for literacy development, the present investigation is aptly called for with respect to the preschool context in Singapore where it has never been studied before. With the use of intervention models from preceding evidence-based studies such as the one by Degé and Schwarzer (2011), the present study can be carried out without an unnecessary the risk of experimental failure. The research question as presented here is: What is the effect of a music curriculum on the reading aptitude of preschool children in Singapore?

\section{The Study}

\subsection{Participating Subjects}

The subjects were recruited by convenience sampling from Kinderland childcare centers. A quasi-experimental group design was employed in order that the child subjects could stay in their existing class grouping for the study. This was to avoid causing them any distress in being placed in a different class or school in the case of a random assignment of experimental and control groups. Hence, this threat to the validity of the data was eliminated by the congeniality of the quasi-experimental design. As for sample size, approximately fifteen participants would be required for a group experiment according to Creswell (2012). Nevertheless, a larger sample would reduce the potential of sampling error.

Following the interest to participate and consent from the children and their parents, data on their age, gender, reading and musical aptitude was collected for the formation of two groups with similar profiles at the start of the study. The total number of subjects found to be suitable was 73 and their profile is shown in Table 1. The subjects from childcare centers offering the music curriculum were assigned as the experimental group $(n=34)$ which received the music intervention; while those from centers that do not offer the music curriculum were assigned as the control group $(n=39)$. The two groups generally shared the same socioeconomic 
background (i.e. middle class) and demographical characteristics by their means to afford the school fees.

Table 1. Profile of subjects

\begin{tabular}{lllllll}
\hline Variable & M & F & Age (Mean) & Age (Min) & Age (Max) & Age (Range) \\
\hline Experimental & 20 & 14 & 5 & 4.6 & 5.5 & 0.9 \\
Control & 14 & 25 & 5.26 & 4.5 & 5.8 & 1.3 \\
\hline
\end{tabular}

To determine if the two groups were comparable in terms of their gender and age, independent t-tests were carried out on the differences stated in the following null hypotheses:

- There is no significant difference between the experimental and control groups' gender means.

- There is no significant difference between the experimental and control groups' age means.

For the first null hypothesis, the numeric value (1) was used for males, and (2) for females. The gender means of the groups were computed as shown in Table 2. A difference of 0.229 is found between the means.

Table 2. Gender means

\begin{tabular}{llllll}
\hline & Group & $\mathrm{N}$ & Mean & Std. Deviation & Std. Error Mean \\
\hline \multirow{2}{*}{ Gender } & Experimental & 34 & 1.41 & 0.5 & 0.086 \\
& Control & 39 & 1.64 & 0.486 & 0.078 \\
\hline
\end{tabular}

Hypothesis testing results in Table 3 show that the difference of 0.229 between the experimental and control groups' gender means is not significant as the t-statistic was found inside the confidence interval; $t(71)=-1.985$, 95\% C.I. $(-.460, .001)$. Therefore, the null hypothesis that there is no significant difference in the experimental and control groups' gender means is not rejected.

Table 3. Gender mean difference

\begin{tabular}{|c|c|c|c|c|c|c|c|}
\hline $\begin{array}{l}\text { Gender t-test for } \\
\text { Equality of } \\
\text { Means }\end{array}$ & $\mathrm{t}$ & df & $\begin{array}{l}\text { Sig. } \\
\text { (2-tail } \\
\text { ed) }\end{array}$ & $\begin{array}{l}\text { Mean } \\
\text { Differenc } \\
\text { e }\end{array}$ & $\begin{array}{l}\text { Std. Error } \\
\text { Differenc } \\
\text { e }\end{array}$ & $\begin{array}{l}95 \% \\
\text { Interval } \\
\text { Difference } \\
\text { Upper }\end{array}$ & $\begin{array}{l}\text { Confidence } \\
\text { of the } \\
\text { Lower }\end{array}$ \\
\hline $\begin{array}{l}\text { Equal variances } \\
\text { assumed }\end{array}$ & -1.985 & 71 & 0.051 & -0.229 & 0.116 & -0.46 & 0.001 \\
\hline $\begin{array}{l}\text { Equal variances } \\
\text { not assumed }\end{array}$ & -1.981 & 69.08 & 0.052 & -0.229 & 0.116 & -0.46 & 0.002 \\
\hline
\end{tabular}

To test the second hypothesis, the age means of the groups were computed as shown in Table 4. A difference of 0.07417 was found between the means.

Table 4. Age means

\begin{tabular}{llllll}
\hline & Group & $\mathrm{N}$ & Mean & Std. Deviation & Std. Error Mean \\
\hline \multirow{2}{*}{ Age } & 1 & 34 & 5.0015 & 0.27784 & 0.04765 \\
& 2 & 39 & 5.0756 & 0.32075 & 0.05136 \\
\hline
\end{tabular}


Hypothesis testing results in Table 5 show that the difference of 0.07417 between the experimental and control groups' age means is not significant as the t-statistic was found inside the confidence interval; $t(71)=-1.048,95 \%$ C.I. $(-.21526, .06691)$. Therefore, the null hypothesis that there is no significant difference in the experimental and control groups' age means was not rejected.

Table 5. Age mean difference

\begin{tabular}{|c|c|c|c|c|c|c|c|}
\hline $\begin{array}{ll}\text { Age t-test } & \text { for } \\
\text { Equality } & \text { of } \\
\text { Means } & \end{array}$ & $\mathrm{t}$ & df & $\begin{array}{l}\text { Sig. } \\
\text { (2-tail } \\
\text { ed) }\end{array}$ & $\begin{array}{l}\text { Mean } \\
\text { Differenc } \\
\text { e }\end{array}$ & $\begin{array}{l}\text { Std. Error } \\
\text { Differenc } \\
\mathrm{e}\end{array}$ & $\begin{array}{l}95 \% \\
\text { Interval } \\
\text { Difference } \\
\text { Upper }\end{array}$ & $\begin{array}{l}\text { Confidence } \\
\text { of the } \\
\text { Lower }\end{array}$ \\
\hline $\begin{array}{l}\text { Equal variances } \\
\text { assumed }\end{array}$ & -1.048 & 71 & 0.298 & & & -0.21526 & 0.06691 \\
\hline $\begin{array}{l}\text { Equal variances } \\
\text { not assumed }\end{array}$ & -1.059 & 70.999 & 0.293 & -0.07417 & 0.07006 & -0.21387 & 0.06552 \\
\hline
\end{tabular}

In summary, the hypothesis testing results on the mean differences of the two groups' gender and age show that the two groups are considered comparable samples.

\subsection{Instrumentation}

The instrument used for measuring the children's Reading Age (R.A.) is the Word Recognition and Phonics Skills (WRAPS 3) test (Moseley, 2008). WRAPS is the only test of children's developing word recognition and phonic skills which provides an objective and reliable diagnostic assessment available in parallel forms A and B. Hence, there is no threat of a practice effect from using the same test after the intervention. It is fully standardized to be used with pupils from 4:6 to 9:0 years and the internal consistency reliability of the test is very high (.97). In addition, it takes account of changes in the relative importance of diagnostic categories as word recognition develops and pinpoints individual strengths and weaknesses in the initial stages of learning to read.

As for their musical aptitude, the instrument used is the Primary Measures of Music Audiation (PMMA) (Gordon, 1979). There are two subtests - Tonal and Rhythm in the PMMA - which take briefly 20-25 minutes each to administer. The PMMA is the only brief, longitudinally valid music aptitude test for Grade K - 3. Participants do not need to read or have prior music instruction to take the test. The reliability for audiation is in the $.90-.92$ range. The test-retest reliability is in the $.73-.76$ range. Although the same test is used for pre- and post-test, the practice effect is largely diminished by the relatively long period of six months in between.

\subsection{Procedure}

Pre-tests and post-tests were carried out at the beginning and at the end of the intervention program for comparison purposes in the study.

3.3.1 Pre-test Measures

Pre-test scores of both groups on the WRAPS and PMMA were tabulated for comparisons. To determine that the two groups were comparable in terms of their R.A. (WRAPS A) and musical aptitude (PMMA Tonal and Rhythm) at the start, the differences were tested in following null hypotheses:

1. There is no significant difference between the experimental and control groups' WRAPS (R.A.) pre-test means.

2. There is no significant difference between the experimental and control groups' PMMA Tonal pre-test means.

3. There is no significant difference between the experimental and control groups' PMMA Rhythm pre-test means. 
After the pretest screening, a 20-week intervention was administered. During this period, the experimental group underwent weekly 60 -minute music sessions at their respective childcare centers. The teachers were trained to carry out the curriculum which consisted of singing, listening, rhythm practice, keyboard playing, ensemble, notation lessons. Literacy skills were incorporated with the use of nursery rhymes, analyzing lyrics, reading children's books associated with great composers, making instruments and other musical concepts, as well as the writing of words, such as songs or names of instruments.

\subsubsection{Post-test Measures}

Post-test means on the WRAPS and PMMA were tabulated with the pre-tests for comparisons. To determine the effects of the music curriculum, the following null hypotheses were tested:

1. There is no significant difference between the experimental and control groups' WRAPS (R.A.) post-test means.

2. There is no significant difference between the experimental and control groups' PMMA Tonal post-test means.

3. There is no significant difference between the experimental and control groups' PMMA Rhythm post-test means.

The alternative directional hypothesis based on the review of literature is that the experimental group which received the intervention (i.e. formal music curriculum) will have significantly higher post-test means than the control group who did not receive the intervention for all the three tests stated above.

\section{Results and Discussion}

\subsection{Pre-test Measures}

Table 6 shows the results of the pre-test means of both groups for their R.A., and musical aptitude.

Table 6. Pre-test means

\begin{tabular}{llll}
\hline Pre-test (means) & Experimental & Control & Experimental - Control \\
\hline WRAPS A & 20.7353 & 22.4872 & -1.7519 \\
PMMA Tonal & 28.0588 & 28.1538 & -0.095 \\
PMMA Rhythm & 25.3824 & 24.5641 & 0.8183 \\
\hline
\end{tabular}

To determine if the groups were comparable in terms of their WRAPS (R.A.) and musical aptitude (PMMA Tonal and Rhythm) at the start of the study, the pre-test hypotheses on the differences as stated earlier were tested.

Table 7. Pre-test WRAPS (R.A.) mean difference

\begin{tabular}{|c|c|c|c|c|c|c|c|}
\hline $\begin{array}{l}\text { WRAPS t-test } \\
\text { for Equality of } \\
\text { Means }\end{array}$ & $\mathrm{t}$ & df & $\begin{array}{l}\text { Sig. } \\
\text { (2-tail } \\
\text { ed) }\end{array}$ & $\begin{array}{l}\text { Mean } \\
\text { Differenc } \\
\text { e }\end{array}$ & $\begin{array}{l}\text { Std. Error } \\
\text { Differenc } \\
\mathrm{e}\end{array}$ & $\begin{array}{l}95 \% \\
\text { Interval } \\
\text { Difference } \\
\text { Upper }\end{array}$ & $\begin{array}{l}\text { Confidence } \\
\text { of the } \\
\text { Lower }\end{array}$ \\
\hline $\begin{array}{l}\text { Equal variances } \\
\text { assumed }\end{array}$ & -0.757 & 71 & 0.452 & -1.75189 & 2.31412 & -6.3661 & 2.86233 \\
\hline $\begin{array}{l}\text { Equal variances } \\
\text { not assumed }\end{array}$ & -0.754 & 68.376 & 0.453 & -1.75189 & 2.3233 & -6.38749 & 2.88372 \\
\hline
\end{tabular}

Hypothesis testing results in Table 7 show that the difference of 1.75189 between the experimental and control groups' WRAPS (R.A.) pre-test means is not significant as the t-statistic was found inside the confidence interval; $t(71)=-.757,95 \%$ C.I. $(-6.36610$, 
2.86233). Therefore, the null hypothesis that there is no significant difference in the experimental and control groups' WRAPS pre-test means is not rejected.

Table 8. Pre-test (PMMA Tonal) mean difference

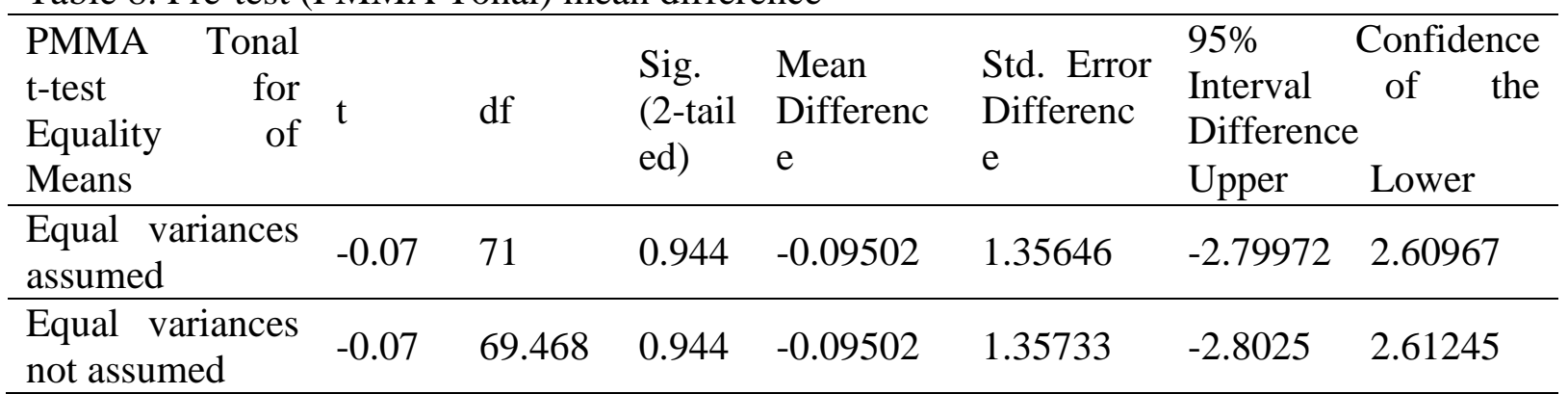

Hypothesis testing results in Table 8 show that the difference of 0.09502 between the experimental and control groups' PMMA Tonal pre-test means is not significant as the $\mathrm{t}$-statistic was found inside the confidence interval; $t(71)=-.070,95 \%$ C.I. $(-2.79972$, 2.60967). Therefore, the null hypothesis that there is no significant difference in the experimental and control groups' PMMA Tonal pre-test means is not rejected.

Table 9. Pre-test (PMMA Rhythm) Mean Difference

\begin{tabular}{|c|c|c|c|c|c|c|c|}
\hline $\begin{array}{lr}\text { PMMA } & \text { Rhythm } \\
\text { t-test } & \text { for } \\
\text { Equality } & \text { of } \\
\text { Means } & \end{array}$ & $\mathrm{t}$ & $\mathrm{df}$ & $\begin{array}{l}\text { Sig. } \\
\text { (2-tail } \\
\text { ed) }\end{array}$ & $\begin{array}{l}\text { Mean } \\
\text { Differenc } \\
\text { e }\end{array}$ & $\begin{array}{l}\text { Std. Error } \\
\text { Differenc } \\
\text { e }\end{array}$ & $\begin{array}{l}95 \% \\
\text { Interval } \\
\text { Difference } \\
\text { Upper }\end{array}$ & $\begin{array}{l}\text { Confidence } \\
\text { of the } \\
\text { Lower }\end{array}$ \\
\hline $\begin{array}{l}\text { Equal variances } \\
\text { assumed }\end{array}$ & 0.71 & 71 & 0.48 & 0.81825 & & -1.48018 & 3.11668 \\
\hline $\begin{array}{l}\text { Equal variances } \\
\text { not assumed }\end{array}$ & 0.713 & 70.524 & 0.478 & 0.81825 & 1.14815 & -1.47135 & 3.10785 \\
\hline
\end{tabular}

Hypothesis testing results in Table 9 show that the difference of 0.81825 between the experimental and control groups' PMMA Rhythm pre-test means is not significant as the $\mathrm{t}$-statistic was found inside the confidence interval; $t(71)=.710,95 \%$ C.I. $(-1.48018,3.11668)$. Therefore, the null hypothesis that there is no significant difference in the experimental and control groups' PMMA Rhythm pre-test means is not rejected.

In summary, the hypothesis testing on pre-test mean differences at the start of the study show that the two groups were considered comparable in terms of their R.A. and musical aptitude as measured by the WRAPS and PMMA Tonal and Rhythm pre-test means.

\subsection{Post-test Measures}

4.2.1 Post-test WRAPS

Figure 2 illustrates the increase in the post-test means of both groups on their WRAPS (R.A.). 


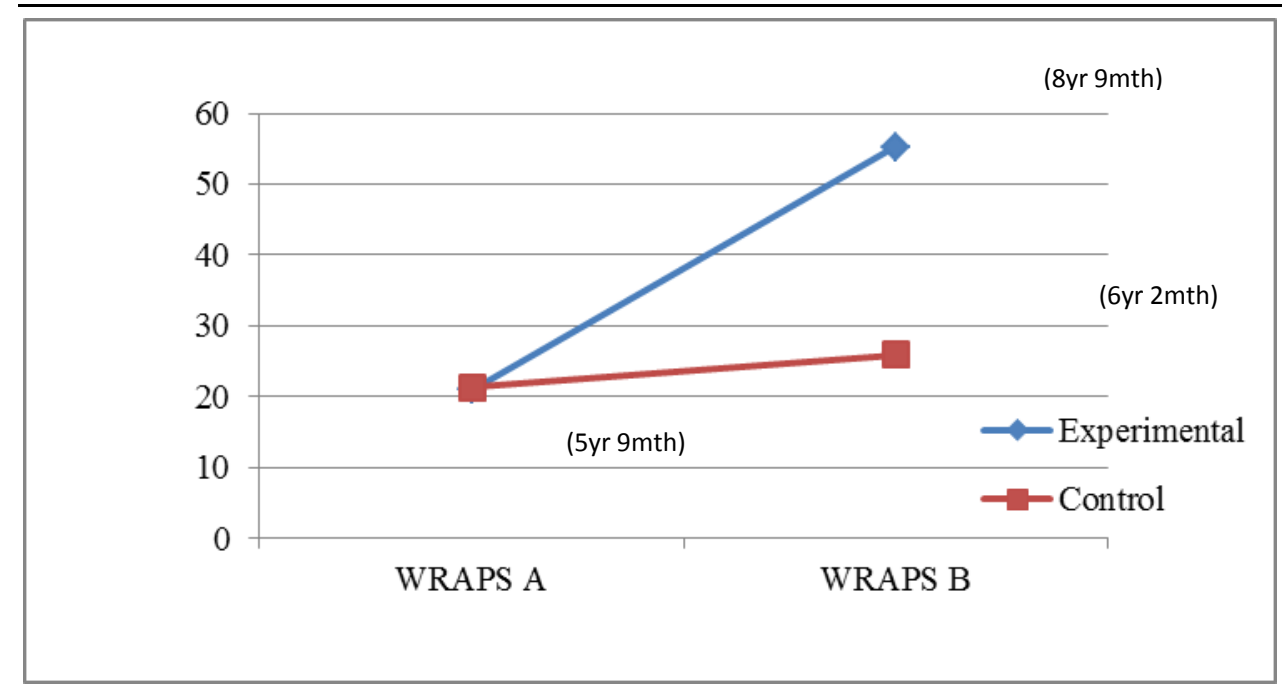

Figure 2. Pre-/Post-test means (WRAPS)

As shown in Table 10, the experimental group's WRAPS post-test means had increased from 5 year 9 months to 8 year 9 months, which is an increase of 3 years 0 months. The control group's R.A. (WRAPS mean) had also increased from 5 year 9 months to 6 year 2 months, but it is a lesser increase of 0 years 5 months.

Table 10. Pre-/Post-test means (WRAPS)

\begin{tabular}{llllr}
\hline Variable & WRAPS A (Pre-test R.A.) & WRAPS B (Post-test R.A.) & \multicolumn{2}{c}{ Post - Pre (means) } \\
\hline Experimental & 20.7353 (5 years 9 months) & 55.2188 (8 years 9 months) & $\begin{array}{l}(3 \text { years } \\
\text { months })\end{array}$ & 0 \\
Control & 22.4872 (5 years 9 months) & 25.9444 (6 years 2 months) & $\begin{array}{l}(0 \text { years } \\
\text { months })\end{array}$ & 5 \\
\hline
\end{tabular}

For the WRAPS post-test, the experimental group had higher scores $(M=55.2188, S D=$ $6.54875)$ than the control $(M=25.9444, S D=9.97409)$. This makes a difference of 29.2743 between the experimental and control groups' post-test means.

Hypothesis testing results in Table 11 show that the difference of 29.2743 between the experimental and control groups' post-test means is significant as the t-statistic was found outside the confidence interval; $t(66)=14.112$, 95\% C.I. $(25.13266,33.41596)$. Therefore, the null hypothesis that there is no significant difference in the experimental and control groups' WRAPS post-test means is rejected.

Table 11. Post-test WRAPS (R.A.) mean differences

\begin{tabular}{llllllll}
\hline $\begin{array}{l}\text { WRAPS t-test } \\
\text { for Equality of } \\
\text { Means }\end{array}$ & & df & $\begin{array}{l}\text { Sig. } \\
\text { (2-tail } \\
\text { ed) }\end{array}$ & $\begin{array}{l}\text { Mean } \\
\text { Differenc }\end{array}$ & $\begin{array}{l}\text { Std. Error } \\
\text { Differenc } \\
\text { e }\end{array}$ & $\begin{array}{l}\text { Interval } \\
\text { Difference } \\
\text { Upper }\end{array}$ & $\begin{array}{l}\text { Lonfidence } \\
\text { of }\end{array}$ \\
\hline $\begin{array}{l}\text { Equal variances } \\
\text { assumed }\end{array}$ & $\begin{array}{l}14.11 \\
2\end{array}$ & 66 & 0 & 29.2743 & 2.07439 & 25.1327 & 33.416 \\
\hline $\begin{array}{l}\text { Equal variances } \\
\text { not assumed }\end{array}$ & 14.45 & 60.986 & 0 & 29.2743 & 2.02573 & 25.2236 & 33.325 \\
\hline
\end{tabular}

With $\mathrm{t}=14.112$ and $\mathrm{df}=66$, the effect size or the percentage of variance accounted for is: $r^{2}=$ 0.75 (or $75 \%$ ). According to the standards used to evaluate $r^{2}$, this value indicates a very large 
treatment effect. Therefore, the null hypothesis for the post-test WRAPS is rejected not just on basis of the significant difference found in the post-test means but on the effect size as well. 4.2.2 Post-test PMMA

As mentioned earlier, the PMMA consists of two subtests - Tonal and Rhythm. Their post-test results will be discussed under two separate sub-sections: PMMA (Tonal) and PMMA (Rhythm).

\subsubsection{Post-test PMMA (Tonal)}

Figure 3 illustrates the increase in the post-test means of both groups on their PMMA (Tonal).

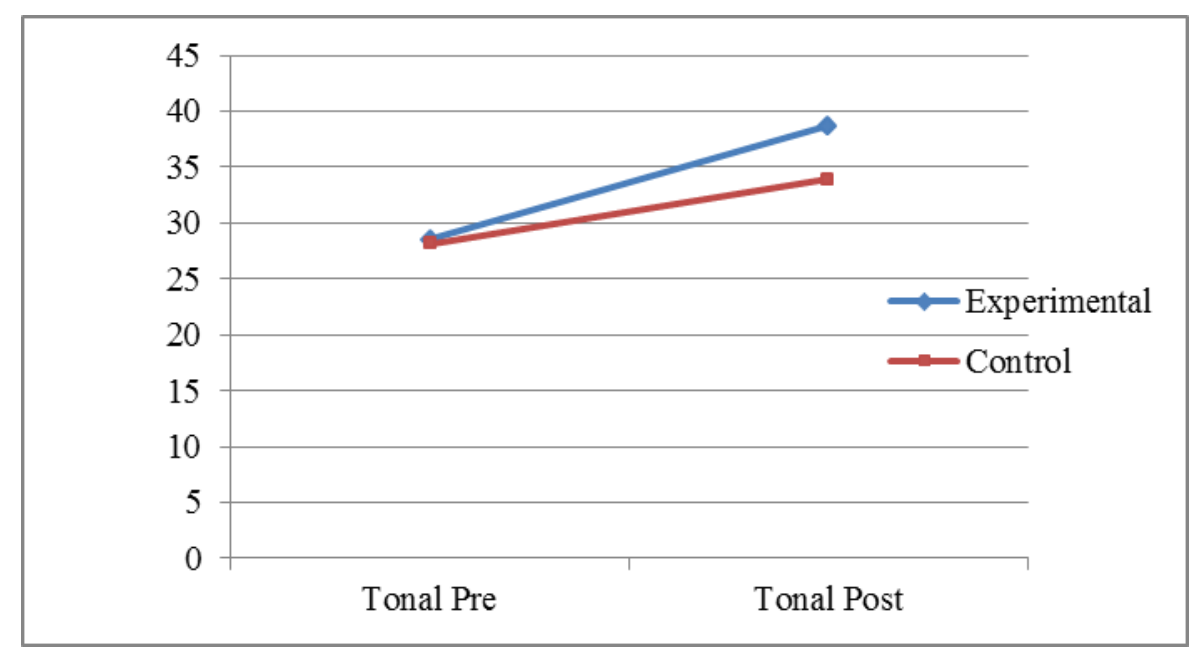

Figure 3. Pre-/post-test means (PMMA Tonal)

As shown in Table 12, the experimental group's PMMA (Tonal) mean had increased from 28.0588 to 38.6875 , which is an increase of 10.6287. The control group's PMMA (Tonal) mean had also increased from 28.1538 to 33.9167 , but it is a lesser increase of 5.7629.

Table 12. Pre-/post-test means (PMMA Tonal)

\begin{tabular}{llll}
\hline Variable & PMMA Tonal (Pre-test) & PMMA Tonal (Post-test) & Post - Pre (means) \\
\hline Experimental & 28.0588 & 38.6875 & 10.6287 \\
Control & 28.1538 & 33.9167 & 5.7629 \\
\hline
\end{tabular}

For the PMMA Tonal post-test means, the experimental group had higher scores $(M=38.6875$, $\mathrm{SD}=1.40132)$ than the control group $(M=33.9167, S D=5.22289)$. This makes a difference of 4.77083 between the experimental and control groups' post-test means.

However, hypothesis testing results in Table 13 show that the difference of 4.77083 is not significant as the t-statistic was found inside the confidence interval; $t(66)=5.006,95 \%$ C.I. $(2.86798,6.67369)$. Therefore, the null hypothesis that there is no significant difference in the experimental and control groups' PMMA Tonal post-test means is not rejected. 
Table 13. Post-test (PMMA Tonal) mean difference

\begin{tabular}{|c|c|c|c|c|c|c|c|c|}
\hline $\begin{array}{l}\text { PMMA } \\
\text { t-test } \\
\text { Equality } \\
\text { Means }\end{array}$ & $\begin{array}{r}\text { Tonal } \\
\text { for } \\
\text { of }\end{array}$ & $\mathrm{t}$ & df & $\begin{array}{l}\text { Sig. } \\
\text { (2-tail } \\
\text { ed) }\end{array}$ & $\begin{array}{l}\text { Mean } \\
\text { Differenc } \\
\text { e }\end{array}$ & $\begin{array}{l}\text { Std. Error } \\
\text { Differenc } \\
\mathrm{e}\end{array}$ & $\begin{array}{l}95 \% \\
\text { Interval } \\
\text { Difference } \\
\text { Upper }\end{array}$ & $\begin{array}{l}\text { Confidence } \\
\text { of the } \\
\text { Lower }\end{array}$ \\
\hline $\begin{array}{l}\text { Equal va } \\
\text { assumed }\end{array}$ & iances & 5.006 & 66 & 0 & 4.77083 & 0.95307 & 2.86798 & 6.67369 \\
\hline $\begin{array}{l}\text { Equal } \\
\text { not assu }\end{array}$ & nces & 5.271 & 40.598 & 0 & 4.77083 & 0.90504 & 2.94251 & 6.59916 \\
\hline
\end{tabular}

\subsubsection{Post-test PMMA (Rhythm)}

Figure 4 illustrates the increase in the post-test means of both groups on their PMMA (Rhythm).

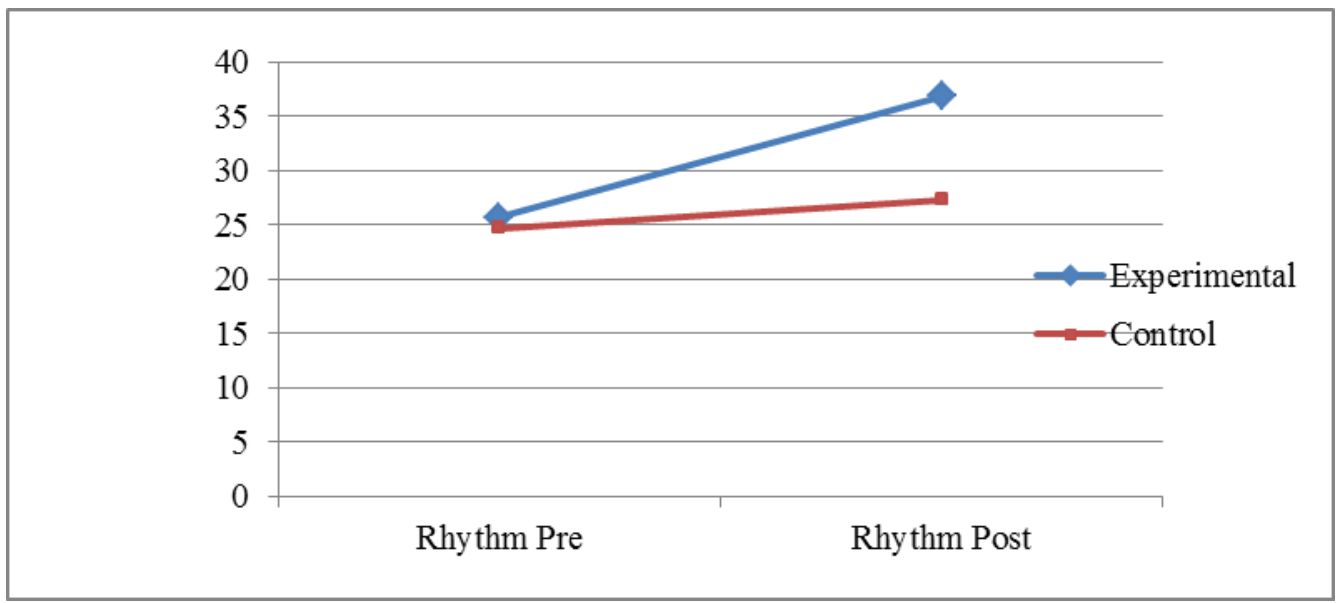

Figure 4. Pre-/post-test means (PMMA Rhythm)

Figure 4 illustrates the increase in the post-test means of both groups on their PMMA (Rhythm). As shown in Table 14, the experimental group's PMMA (Rhythm) mean had increased from 25.3824 to 36.8438 , which is an increase of 11.4614. The control group's PMMA (Rhythm) mean had also increased from 24.5641 to 27.3333 , but it is a lesser increase of 2.7692 .

Table 14. Pre-/post-test means (PMMA Rhythm)

\begin{tabular}{llll}
\hline Variable & PMMA Rhythm (Pre-test) & PMMA Rhythm (Post-test) & Post - Pre (means) \\
\hline Experimental & 25.3824 & 36.8438 & 11.4614 \\
Control & 24.5641 & 27.3333 & 2.7692 \\
\hline
\end{tabular}

For the PMMA Rhythm post-test means, the experimental group had higher scores $(M=$ $36.8438, \mathrm{SD}=2.00176)$ than the control $(M=27.3333, S D=4.56070)$. This makes a difference of 9.51042 between the experimental and control groups' post-test means.

However, hypothesis testing results in Table 15 show that the difference of 9.51042 between the experimental and control groups' post-test (means) is not significant as the t-statistic was found inside the confidence interval; $t(66)=10.894$, 95\% C.I. $(7.76735,11.25349)$. Therefore, the null hypothesis that there is no significant difference in the experimental and control groups' PMMA Rhythm post-test means is not rejected. 
Table 15. Post-test (PMMA Rhythm) mean difference

\begin{tabular}{|c|c|c|c|c|c|c|c|}
\hline $\begin{array}{lr}\text { PMMA } & \text { Rhythm } \\
\text { t-test } & \text { for } \\
\text { Equality } & \text { of } \\
\text { Means } & \\
\end{array}$ & $\mathrm{t}$ & df & $\begin{array}{l}\text { Sig. } \\
\text { (2-tail } \\
\text { ed) }\end{array}$ & $\begin{array}{l}\text { Mean } \\
\text { Differenc } \\
\text { e }\end{array}$ & $\begin{array}{l}\text { Std. Error } \\
\text { Differenc } \\
\text { e }\end{array}$ & $\begin{array}{l}95 \% \\
\text { Interval } \\
\text { Difference } \\
\text { Upper } \\
\end{array}$ & $\begin{array}{l}\text { Confidence } \\
\text { of the } \\
\text { Lower }\end{array}$ \\
\hline $\begin{array}{l}\text { Equal variances } \\
\text { assumed }\end{array}$ & $\begin{array}{l}10.89 \\
4\end{array}$ & 66 & 0 & 9.51042 & 0.87304 & 7.76735 & 11.2535 \\
\hline $\begin{array}{l}\text { Equal variances } \\
\text { not assumed }\end{array}$ & $\begin{array}{l}11.34 \\
3\end{array}$ & 49.205 & 0 & 9.51042 & 0.83845 & 7.82567 & 11.1952 \\
\hline
\end{tabular}

In summary, the hypothesis testing on post-test mean differences at the end of the intervention showed that the two groups were considered not comparable in terms of their R.A. as measured by WRAPS, but comparable in their musical aptitude, as measured by PMMA Tonal and Rhythm post-test means.

\section{Results and Discussion}

The hypothesis testing of post-test results showed that the experimental group which received the intervention (i.e. formal music curriculum) achieved significantly higher post-test means than the control group who did not receive the intervention for the WRAPS test. This implies that the intervention had a significant positive effect on the children's reading age.

Although the post-test means of both groups in the Tonal and Rhythm tests were not significantly different by hypothesis testing, the experimental group did outperform the control group in post-test means by 4.77083 points for PMMA Tonal, and 9.51042 points for PMMA Rhythm.

Thus, the present study adds to the body of research studies which show that positive musical aptitude can have a positive effect on reading aptitude as early as preschool. The implication is that formal music curriculum can be used as an efficient complementary educational approach to facilitate the development of linguistic abilities. Consequently, reading difficulties may be reduced when children enter primary school.

It is instrumental to note that the effects of the present study were validated by controlling the sample in terms of the similar profile in gender, age and socio-economic status, as well as word recognition and musical aptitude to start with. As a random group assignment would pose the threat of distress to the subjects, a quasi-experimental design was used to facilitate a more accurate measure of their true potential under their natural class groupings. This was to improve the validity of their performance. In addition, mortality factors were controlled by a sample size that is larger than 15 subjects required for a group experiment according to Creswell (2012). Furthermore, maturational factors were accounted for by the comparison of the post-test means of the control group which did not receive the intervention.

Nevertheless, the effects may be limited to the context of the study, especially in terms of the intervention - the curriculum used (proprietary to Kinderland), teaching styles, and classroom environment; as well as the demographics - the sample in the present study had similar profiles as mentioned. It should also be noted that children with diagnosed learning disabilities were not included in the present study.

Since this is the first study carried out on the effect of a preschool music curriculum on children's reading aptitude in Singapore, further research is recommended to validate the effects for groups with dissimilar demographics, including those at risk of reading difficulties. It is hoped that research and testing would not only bring about a positive impact on children's literacy development, but also value-added knowledge for the various stakeholders in the early childhood sector as well. 


\section{Acknowledgement}

This one-year research study was funded by the Early Childhood Development Agency, Singapore, No. ECRF-13-02, from June 2013 to June 2014.

\section{References}

Anwari, S. H., Trainor, L. J., Woodside, J., \& Levy, B. (2002). Relations among musical skills, phonological processing and early reading ability in preschool children. Journal of Experimental Child Psychology, 83, 111-130.

Ashcraft, M. (2006). Learning and remebering. In J. Mosher \& M. Richardson (Eds.), Cognition (pp. 211-256). Upper Saddle River, NJ: Pearson Prentice-Hall

Besson, M., \& Schon, D. (2003). Comparison between language and music. In I. Peretz \& R. J. Zatorre (Eds.), The Cognitive Neuroscience of Music (pp. 269-293). Oxford, UK: Oxford University Press

Bolduc, J. (2009). Effects of a music programme on kindergartners' phonological awareness skills. International Journal of Music Education, 27(1), 37-47.

Brown, S., Martinez, M., \& Parson, L. (2006). Music and language side by side in the brain: A PET study of the generation of melodies and sentences. European Journal of Neuroscience, 23, 2791-2803.

Chazin, S., \& Neuschatz, J. S. (1990). Using a mnemonic to aid in the recall of unfamiliar information. Perceptual Motor Skills, 71, 1067-1071.

Creswell, J. W. (2012). Educational research: Planning, conducting, and evaluating quantitative and qualitative research (4th ed.). Boston, MA: Pearson Education.

Degé, F., \& Schwarzer, G. (2011). The effect of a music program on phonological awareness in preschoolers. Frontiers In Psychology, 2, 124-124. doi: 10.3389/fpsyg.2011.00124

Ehri, L. C., \& McCormick, S. (1998). Phases of word-learning: Implications for instruction with delayed and disabled readers. Reading and Writing Quarterly: Overcoming learning difficulties, 14, 135-163.

François, C., Chobert, J., Besson, M., \& Schön, D. (2013). Music training for the development of speech segmentation. Cerebral Cortex, 23(9), 2038-2043.

Fredorenko, E., Patel, A., Casasanto, D., Winawer, J., \& Gibson, E. (2009). Structural integration in language and music: Evidence for a shared system. Memory \& Cognition, 37, $1-9$.

Gfeller, K. (1983). Music mnemonics as an aid to retention with normal and learning disabled students. Journal of Music Therapy, 20, 179-189.

Gordon, E. E. (1979). Primary measures of music audiation. Chicago, IL: G.I.A. Publications. Huslander, J., Talcott, J., Witton, C., DeFries, J., Pennington, B., \& Wadsworth, S. (2004). Sensory processing, reading, IQ, and attention. Journal of Experimental Child Psychology, 88, 274-295.

Koelsch, S., Gunter, T. C., Wittfoth, M., \& Sammler, D. (2005). Interaction between syntax processing in language and in music: An ERP Study. Journal Of Cognitive Neuroscience, 17(10), 1565-1577.

McElhinney, M., \& Annett, J. M. (1996). Pattern of efficacy of a musical mnemonic on recall of familiar words over several presentations. Perceptual and Motor Skills, 82, 395-400.

Moreno, S., Bialystok, E., Barac, R., Schellenberg, E. G., Cepeda, N. J., \& Chau, T. (2011). Short-term music training enhances verbal intelligence and executive function. Psychological Science, 22(11), 1425-1433. doi: 10.1177/0956797611416999

Moseley, D. (2004). The diagnostic assessment of word recognition and phonic skills in five-year-olds. Journal of Research in Reading, 27(2), 132-140. doi: 10.1111/j.1467-9817.2004.00221.x 


\section{MInstitute Macrothink $_{\text {int }}$}

Moseley, D. (2008). Word Recognition and Phonic Skills (WRaPS)-3 ${ }^{\text {rd }}$ Ed. London, UK: Hodder Education.

Pennington, B. F., Peterson, R. L., \& Mcgrath, L. M. (2009). Dyslexia. In B. F. Pennington (Ed.), Diagnosing Learning Disorders: A neuropsychological framework (2nd ed., pp. 45-82). New York, NY: The Guilford Press

Rainey, W. D., \& Larsen, J. D. (2002). The effect of familiar melodies on initial learning and long term memory for unconnected text. Music Perception, 20, 173-186.

Samson, S., \& Zatorre, J. (1991). Recognition for text and melody of songs after unilateral temporal lobe lesion: Evidence for dual encoding. Journal of Experimental Psychology: Learning, Memory and Cognition, 17, 793-804.

Schon, D., Boyer, M., Moreno, S., Besson, M., Peretz, I., \& Kolinsky, R. (2008). Songs as an aid for language acquisition. Cognition, 106(2), 975-983. doi: 10.1016/j.cognition.2007.03.005

Schon, D., Gordon, R., Campagne, A., Magne, C., Astesano, C., Anton, J. L., \& Besson, M. (2010). Similar cerebral networks in language, music and song perception. Neuroimage, 51(1), 450-461. doi: 10.1016/j.neuroimage.2010.02.023

Schon, D., Gordon, R. L., \& Besson, M. (2005). Musical and linguistic processing in song perception. Annals of the New York Academy of Sciences, 1060, 71-81. doi: 10.1196/annals.1360.006

Wallace, W. (1994). Memory for music: Effect of melody on recall of text. Journal of Experimental Psychology: Learning, Memory and Cognition, 20, M71-M78.

Wigram, T., \& Gold, C. (2006). Music therapy in the assessment and treatment of autistic spectrum disorder: clinical application and research evidence. Child: Care, Health and Development, 32(5), 535-542. doi: 10.1111/j.1365-2214.2006.00615.x

\section{Copyright Disclaimer}

Copyright for this article is retained by the author(s), with first publication rights granted to the journal.

This is an open-access article distributed under the terms and conditions of the Creative Commons Attribution license (http://creativecommons.org/licenses/by/3.0/). 